\title{
Problems of Russian heat supply and ways of their solution
}

\author{
Valery Stennikov ${ }^{1}$, and Andrey Penkovskii ${ }^{1 *}$ \\ ${ }^{1}$ Melentiev Energy Systems Institute of Siberian Branch of the Russian Academy of Sciences, \\ Laboratory of Heat Supply Systems, 664033 Irkutsk, Russia
}

\begin{abstract}
Heat supply in Russia, most of which is located in a territory with a harsh climate, is the most important social sector of the economy, largely determining the country's energy security. Over the past period of reforming in the heat supply many problems have accumulated. This is due, first of all, to the lack of effective mechanisms for managing their functioning and development. At the same time, there is every reason to believe that the target model of the heat market adopted by the Government of the Russian Federation not only does not eliminate these problems, but further aggravates the situation
\end{abstract}

Keywords: district heating system; heat market; unified heat supply organization; alternative boiler station.

\section{Introduction}

District heating (DH) plays an important role in providing heat to consumers in many countries around the world. Its most common form is combined (cogeneration) production of heat and electricity at combined heat and power plants (CHP), which allows to save up to $40 \%$ of primary fuel. Unlike other energy systems (electricity, oil supply, gas supply), DH systems are local markets operating in a limited area. According to some expert estimates, there are currently about 80,000 heat energy markets in the world [1] of which 50,000 are located in the Russian Federation [2] about 6,000 in the European Union [3], the remaining 24,000 are in China, USA, Ukraine, Belarus, Kazakhstan, etc.

The processes of liberalization in the heat power industry, which began in the $90 \mathrm{~s}$ after the collapse of the USSR, led to the formation of new economic relations among producers, suppliers and consumers of heat energy, a change in the form of ownership and a transition to self-sufficiency of the services provided. As a result of the transformations, the business inherited huge funds from the USSR and, which is very important, the market for prepared consumers, but it was not ready to work in market conditions. Despite the cardinal organizational and technological changes that were supposed to contribute to evolution, the administrative scheme of management is still maintained in heat supply, the dictate of suppliers over consumers remains, the reliability of heat supply decreases, tariffs are

\footnotetext{
* Corresponding author: penkoffsky@isem.irk.ru
} 
growing. All this leads to consumers leaving DH systems. As a result, heat energy companies are gradually losing all the successes achieved in district heating during the Soviet period. DH systems in Russian, which accounts for $72 \%$ of heat supply, is the main type of heat supply to consumers.

\section{New model of district heating market in Russia}

In 2010, the main Federal Law "On heat supply" [4] was adopted. Its adoption was associated with fundamental changes in the political, socio-economic life of the country to solve the problem of providing reliable and uninterrupted supply of heat energy to consumer. During the period 2010-2020, the Federal Law "On heat supply" was revised several times by introducing amendments to its main text, as well as additions to its separate normative acts.

In the amendments adopted in 2018 to the Federal Law "On heat supply" and the Roadmap "Implementation of the target model of the heat market" proposed by the Government of the Russian Federation, a new model of the heat market was established, implying a transition to the Unified heat supply organization (UHSO), created on the basis of large heat sources and heating networks. The statutory tariff setting system is based on the price of heat energy determined by the "alternative boiler station" (ABS) method. The main goal of these innovations was to reduce administrative pressure on the heat business and create economic incentives to attract investment and improve the current state of DH systems. Within the framework of this model, it is proposed to expand the role of the UHSO, which should not only act as a single purchaser and supplier of heat energy in the area of its activity, but will become a single center of responsibility in the DH system to consumers and authorities. The new model of the heat market involves the transition from state regulation of all tariffs in the field of heat supply to contractual prices for heat energy. At the same time, in order to protect consumers, the heat energy tariff is limited by the estimated cost of heat energy produced by the ABS. The ABS refers to a local heat source with a capacity of no more than $40 \mathrm{GJ} / \mathrm{h}$, which the consumer can use to replace the district heat supply [5]. The basis for determining the parameters of the ABS is the premise of using the most modern and cost-effective technologies, as well as the most efficient use of the installed capacity of the ABS. In the process of modeling, based on a number of input parameters (technological and economic), in accordance with an acceptable payback period for the investor (no more than 10 years), the level of the tariff for the heat energy produced in the region is calculated based on the total discounted costs for the construction and operation of the ABS. If the current tariff for heat energy is lower than the ABS price, then a schedule has been developed for a phased (within 5 years) bringing the current tariff for heat energy up to the ABS price, taking into account the indexation of the corresponding prices, approved by the Government of the Russian Federation. If the current tariff is higher than the ABS price, it is frozen.

Bringing the tariff level to the price of an "alternative boiler house", according to many experts [6-9], contradicts the main strategic direction of heat supply development cogeneration (the most economical method of producing heat and electricity), since it leads to a decrease in its competitiveness relative to other types of heat supply and thus will contribute to the outflow of consumers and stagnation of DH systems. The most reasonable (acceptable) would be not to strive for the price of the ABS, but to use the experience of European countries with large DH systems based on cogeneration, in which the price of the ABS for the consumer acts as a limit value for heat energy for DH systems. For UHSO necessary to create conditions at the level of heating networks (as an object of natural monopoly) for open access to the connection of new heat sources to create competition among various heat energy producers [10-12]. 
A publicly available calculator for calculating the cost of heat using the "alternative boiler house" method, posted on the website of the Ministry of Energy of the Russian Federation, showed that for many regions of Russia the transition to a new model of the heat market will lead to a sharp increase in tariffs for heat energy for the consumers table 1.

Table 1. Technical Current tariffs for heat energy and tariffs calculated using the

ABS method in cities with large district heating systems

\begin{tabular}{|c|c|c|c|}
\hline City & Fuel & $\begin{array}{c}\text { Current tariff, } \\
\text { EUR/JG }\end{array}$ & $\begin{array}{c}\text { Tariff ABS, } \\
\text { EUR/JG }\end{array}$ \\
\hline Moscow & Natural gas & 3.77 & 6.01 \\
\hline Krasnoyarsk & Coal & 4.44 & 7.04 \\
\hline Novosibirsk & Coal & 3.36 & 6.86 \\
\hline Kazan & Natural gas & 4.44 & 5.16 \\
\hline Omsk & Coal & 4.96 & 6.58 \\
\hline Saint Petersburg & Natural gas & 4.63 & 7.30 \\
\hline Irkutsk & Coal & 3.50 & 7.23 \\
\hline Ulan-Ude & Coal & 5.25 & 7.31 \\
\hline Tyumen & Natural gas & 4.33 & 4.60 \\
\hline Tomsk & Natural gas & 4.50 & 5.50 \\
\hline
\end{tabular}

For large DH systems in Russia, the transition to a new model of the heat market can provoke a serious increase in the tariff for heat energy by 1.5 times or more. This necessitates additional justification for the introduction of such a model of the heat energy market into real practice in each specific case.

\section{Conclusion}

In the process of the reforms in the energy sector, heat supply in Russia has largely lost the successes achieved during the Soviet period. This is confirmed by many negative trends, which are manifested in a decrease in the level of district heating, an increase in the number of small less economical boiler stations, a reduction in the length of heating networks of district heating systems, an increase in unproductive losses of heat energy, etc. The measures proposed in the Federal Law "On heat supply" to organize a new model of the heat market 
"EHSO + ABS", designed to stimulate the inflow of investments, do not solve the pressing problems, but exacerbate them even more. To change the current situation in heat supply, it is necessary to legislatively change the model of organizing heat supply with the organization of EHSO only for a naturally monopoly sphere of activity - the transfer and distribution of heat energy through heat networks. The ABS price should only be the maximum indicative level.

The research was performed at Melentiev Energy Systems Institute SB RAS in the framework of a scientific projects III.17.4.3. № AAAA-A17-117030310437-4 of the foundation researches program of $S B R A S$

\section{References}

1. S. Frederiksen, , S. Werner, District Heating and Cooling (Lund Studentlitteratur, 2013)

2. P. Vasant, , N. Voropai, Sustaining power resources through energy optimization and engineering (Hershey PA, 2016)

3. S. Werner, Energy, 137, 617 (2017)

4. Russian Federation Federal law of 27.07.2010 No.190-FL [in Russian]

5. S.V. Zarenkov, E.H. Dosalin, A.B. Bogdanov, Energy and Housing and communal services, 3(38), 47 (2016)

6. V. A. Stennikov, A.V. Penkovskii, ECO, 3, 8 (2019) [in Russian]

7. E.G. Gasho, The heat supply industry is reborn today. Energosberezhenie, 7, 28 (2013) [in Russian]

8. V. Stennikov, G. Slavin, Energy market, 2, 22 (2014) [in Russian]

9. A.A. Makarov, N.I. Voropai, V.A. Stennikov, Systems research in the energy: methodology and results (Moscow, ERI RAS, 2018) [in Russian]

10. S. Wenren, Energy, 126, 419 (2017)

11. S. Paiho, H. Saastamoinen, Energy Policy, 122, 668 (2018)

12. Wissner, M. Utilities Policy, 31, 63 (2014) 